\title{
Limb morphology of the carnivorous anomopods Anchistropus emarginatus Sars, 1862 and Pseudochydorus globosus (Baird, 1843) (Crustacea: Branchiopoda: Anomopoda)
}

\author{
K. Van Damme, H.J. Dumont
}

Limnology Research Group, Department of Biology, Ghent University, K.L. Ledeganckstr. 35, B-9000 Ghent, Belgium. E-mail: kay.vandamme@ugent.be

\begin{abstract}
We studied the morphology of two 'flesh-eating' Chydoridae Anchistropus emarginatus Sars, 1862 and Pseudochydorus globosus (Baird, 1830), using populations from Belgium, with particular attention to the structure of the trunk limbs. Both genera belong in subfamily Chydorinae, and both have morphological adaptations with implications for the interpretation of limb morphology in the subfamily. Anchistropus has a large number of specific characters, many of which directly relate to the animal's habit of feeding on Hydra. In Pseudochydorus globosus, specializations are less numerous. A redescription of both species is offered, with an aim at allowing future comparisons with populations outside the Palaearctic, where cryptic species are expected to occur.
\end{abstract}

Keywords: Anchistropus emarginatus, Pseudochydorus globosus, Chydorinae evolution, morphology, trunk limbs.

\section{Introduction}

The Chydoridae are small anomopod crustaceans, whose ecological preferences encompass a wide range of specializations. The majority is specialized for life in the pelagic, littoral or benthos, feeding on phytoplankton, periphyton or detritus. Few taxa have developed a taste for a protein-rich diet, and have adopted a carnivorous lifestyle, rare among chydorids. Two genera have been found to feed on animal tissue (Fryer 1968): the conspicuous Anchistropus Sars, 1862 and Pseudochydorus (Baird, 1843); these form the basis of the present study.

Of Anchistropus Sars, 1862, two species have been described well enough to be taxonomically acceptable: $A$. emarginatus Sars, 1862 from Europe and A. ominosus Smirnov, 1985 from Brazil. Even here, however, the trunk limbs have not been given the attention they deserve. The status of A. minor Birge, 1893, a name used for North American populations (Smirnov 1996), needs confirmation by a comparison with the European $A$. emarginatus. Superficially similar to Chydorus, Anchistropus is often but erroneously referred to as a "parasite" of Hydra (Borg 1935, Fryer 1968). Freshwater polyps constitute the main diet of Anchistropus, and their association has been noted for A. emarginatus as well as for $A$. minor (Hyman 1926, Fryer 1968). Using the strong hooks on the first trunk limb, these small chydorids tears ectodermal tissue off the cnidarians (Fig. 1), eventually kil-

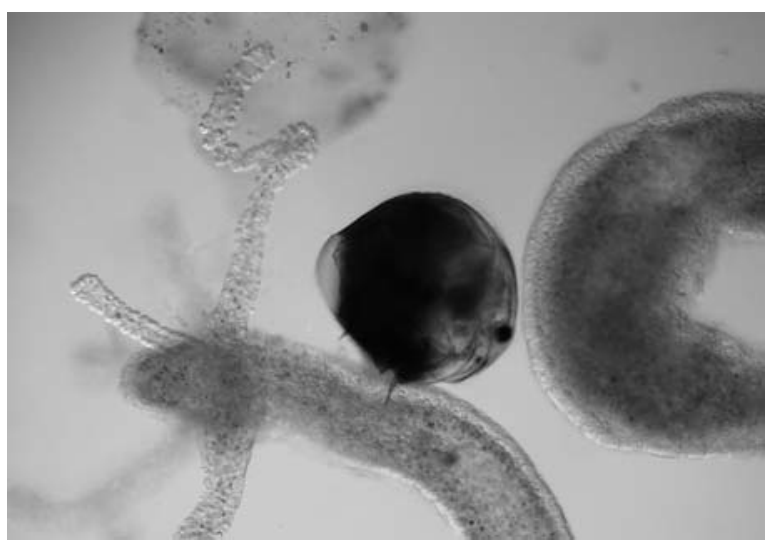

Fig. 1. Adult parthenogenetic female of Anchistropus emarginatus feeding on live Hydra. The chydorid cladoceran uses its specially adapted hooks on the first limb for tearing ectodermal cells from the freshwater polyp.

ling the latter (Borg 1935, Hyman 1926). A. emarginatus is rare and easily overlooked; it was only recorded from Belgium twice (Luyten 1934, Smirnov 1992) despite intensive sampling (Louette et al. 2007).

The second carnivorous chydorid, Pseudochydorus, is a monotypic genus, with type species Pseudochydorus globosus (Baird, 1843). The geographical range of this taxon extends over several continents (Smirnov 1996) and it is commonly found in temperate as well as tropical waterbodies. Several cryptic species may hide under the 
name globosus, but remain to be described (Hollwedel et al. 2004), as so often when different populations of socalled cosmopolitan chydorids are examined carefully (Frey 1987).

Both Anchistropus and Pseudochydorus have a superficially similar, chydorine habitus. Sars (1862) and Lilljeborg (1901) noted about the young instars: "Wenn schon kleiner, errinert sie (Anchistropus) beim ersten Anblick an Chydorus globosus (Pseudochydorus)". Fryer (1968) went a step further and suggested that Pseudochydorus and Anchistropus are phylogenetically close: "Phyletic affinity with Pseudochydorus is clear, and the two may have had a common proximate ancestor." He also studied the feeding mode and morphology of Anchistropus, concluding that it is more closely related to Pseudochydorus than to any other chydorid. However, the evidence for such a close affinity of both genera is not strong. We here test it by a full morphological analysis of the trunk limbs. Some basics of the structure of the thoracic limbs of Pseudochydorus were pictured by Sars (1861), and of Anchistropus by Sars (1861), Lilljeborg (1901) and Fryer (1968) but to date remain unexploited from a taxonomical point of view. Sars (1861) noted the modified hook on the first limb of Anchistropus, providing the inspiration for the genus name (from "ankistron", hook and "pous", foot). Lilljeborg (1901) depicted the male and female of A. emarginatus with care (Lilljeborg 1901: plate 79, figs 7-21), including most limbs and included a comparison with Chydorus (at the time still including Pseudochydorus) and Smirnov (1971) provided additional drawings of the limbs of A. emarginatus and P. globosus. However, in recent years our knowledge of the limbs of the Chydoridae has increased considerably, as has the amount of detail needed to describe them adequately (Dumont $\& \mathrm{Ne}-$ grea 2002).

Here, our aim is to bring the level of knowledge on the trunk limbs of Pseudochydorus globosus and Anchistropus emarginatus up to current standards, in order to make them available as a tool for phylogenetic studies and to facilitate future comparisons with populations elsewhere in the world. We also to discuss the specializations and evolutionary placement of both genera within the family.

\section{Materials and methods}

All animals were collected using plankton nets of $65 \mu \mathrm{m}$ mesh width. For obtaining Anchistropus, we rinsed submerged macrophytes (Potamogeton pectinatus) off in the net. SEM micrographs were prepared using a dehydration series in ethanol. Animals were critical point dried, sputtered with gold and photographed under a JEOL-JSM 840 scanning electron microscope at
Ghent University. The photo of live Anchistropus on Hydra, collected in Ghent, was taken with an Olympus digital camera mounted on an Olympus stereomicroscope. Drawings of morphological structures were made using a drawing tube mounted on a Leitz Orthoplan II microscope using dark field illumination. For orientation of limbs and numbering of setae, there are different methods (Kotov 2000). We here use a clockwise numbering for limbs 2-5, from epipodite to gnathobase (away from epipodite) for setae in exopodite and endopodite as in Van Damme et al. (2007). Filter comb setae are indicated by letters and sensilla indicated as such; like the postabdomen, limbs are oriented with ventral side up.

\section{Taxonomic account}

\section{Genus Anchistropus Sars, 1862}

Anchistropus emarginatus Sars, 1862

Specimens examined: two parthenogenetic females from the Diver's Training Basin (Duikersput) in the Blaarmeersen, Ghent, Belgium (leg. B. Rumes and M. Fagot, 16/06/2006); 15 parthenogenetic females from the Boatracing canal (Watersportbaan), an extension of the Leie River in Ghent, Belgium (leg. K. Van Damme \& D. Van Damme, 25/08/2006); two parthenogenetic females from a permanent water, 'Zandwinningsput aan Electrabel' in Mol, Belgium (leg. K. Van Damme \& D. Van Damme, 15/09/2006); two parthenogenetic females, Damvalleimeer, Destelbergen, Belgium (leg. K. Van Damme, 20/10/2006).

\section{Redescription of the parthenogenetic female}

Habitus (Figs 2A-C \& 3A-B). Globular in lateral view, body tapering posteriorly (Figs $2 \mathrm{~A}-\mathrm{C} \& 3 \mathrm{~A}$ ). Dimensions: body height/length $0.85-0.9$, adult size 0.35 $0.42 \mathrm{~mm}$. Eye very large (Sars 1861) and ocellus small, antennule not reaching rostral tip. Head shield of the Chydorus type (Frey 1959); pore arrangement typical for chydorines: two major pores with small pores in between on midline (depicted in Floessner 2001), main pores situated at large distance from one another, distance between major pores slightly larger than distance between posterior pore and posterior head shield margin; distance between anterior pore and rostrum twice interpore distance. Valves pigmented and strongly thickened, creating a dark brown to black appearance (Figs $1 \& 2 B-C)$. Pigment spots vary in size and shape, but always cover central region of body (Figs 2B-C). Carapace ornamentation hexagonal patterns with wavy outlines (Fig. 2H); in life carapace surrounded by gelatinous layer of about $20 \mu \mathrm{m}$ (Fryer 1968). Ventral 


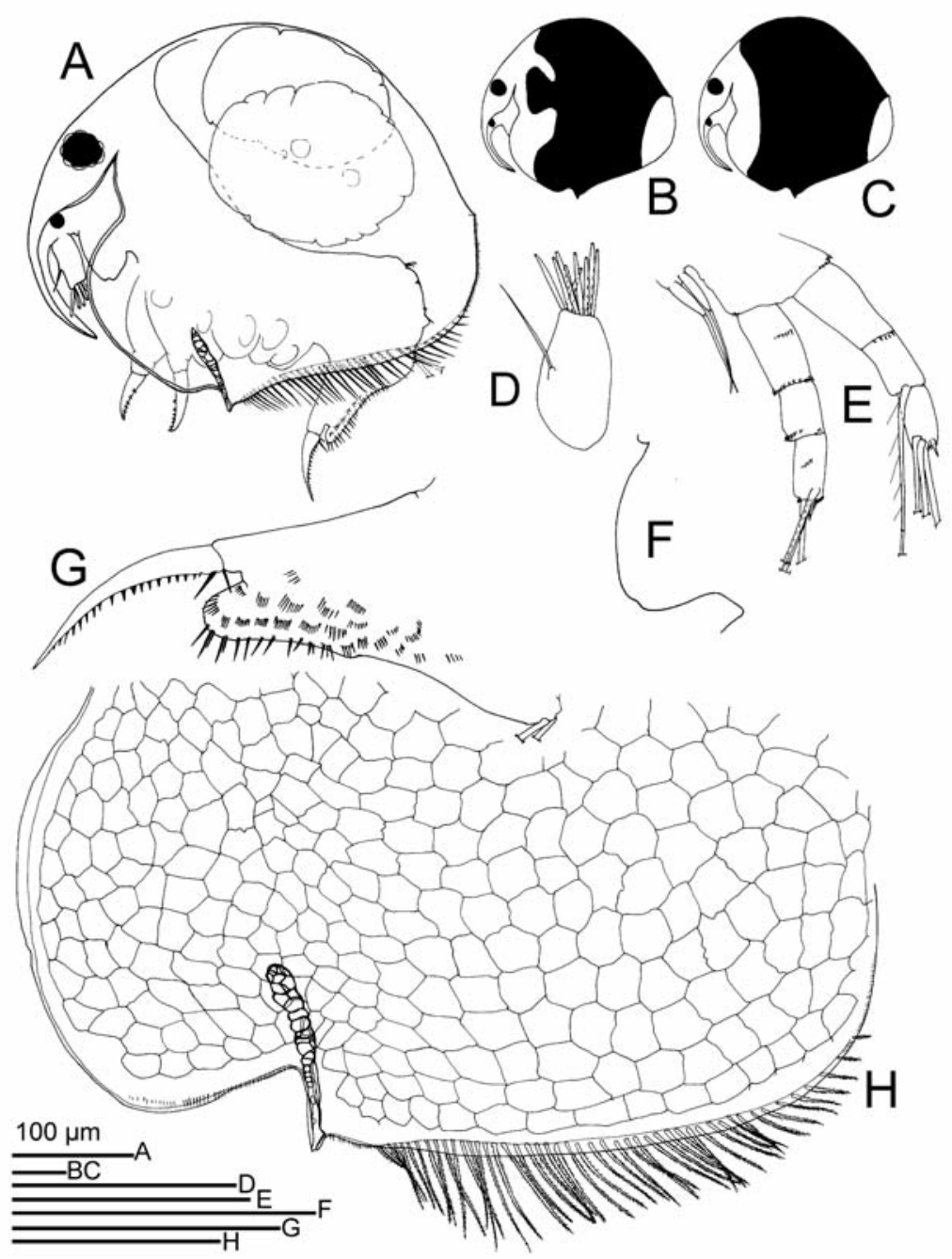

Fig. 2. Anchistropus emarginatus Sars, adult parthenogenetic female from Belgium. A. Habitus, lateral view, pigment field not shown; B-C. Habitus, lateral view, variation in pigmentation of carapace; D. Antennule; E. Second antenna; F. Labrum, lateral view; G. Postabdomen, lateral view; I. Carapace and setulation.

margin without flange (Fryer 1968). Ventral invagination before midline of body, (Figs 2A, $2 \mathrm{H} \& 3 \mathrm{~A}$ ), followed by protruding tip ("tooth") and wide, "heart-shaped" (Sars 1861) opening in ventral margin of valves (Fig. 3B). Posterior ridge of ventral embayment with large cells (under light microscopy; Fig. 2H) while SEM reveals inner lateral ridge on carapace (Fig. 3C). No gland found here (Fryer 1968). Marginal setae reduced to minute setules anteriorly to embayment; posterior half with long marginal setae extending well beyond valve margin, decreasing in size towards posteroventral corner (Fig. 2H).
Antennule (Fig. 2D) with stout body and nine short aesthetascs of different size; sensory seta implanted about halfway on antennular body. Second antenna (Fig. 2E) relatively short, with long coxal setae; antennal formula 003/013 for setae, 001/001 for spines. Minute denticles on margins of segments; apical spines on exo- and endopodite short. Labrum (Fig. 2F) small and round, with indented tip.

Postabdomen (Fig. 2G). Short, narrowing distally. Dorsal margin projecting ventrally, deep embayment between base of terminal claw and postanal margin. Lateral denticles small and fine, not reaching beyond 


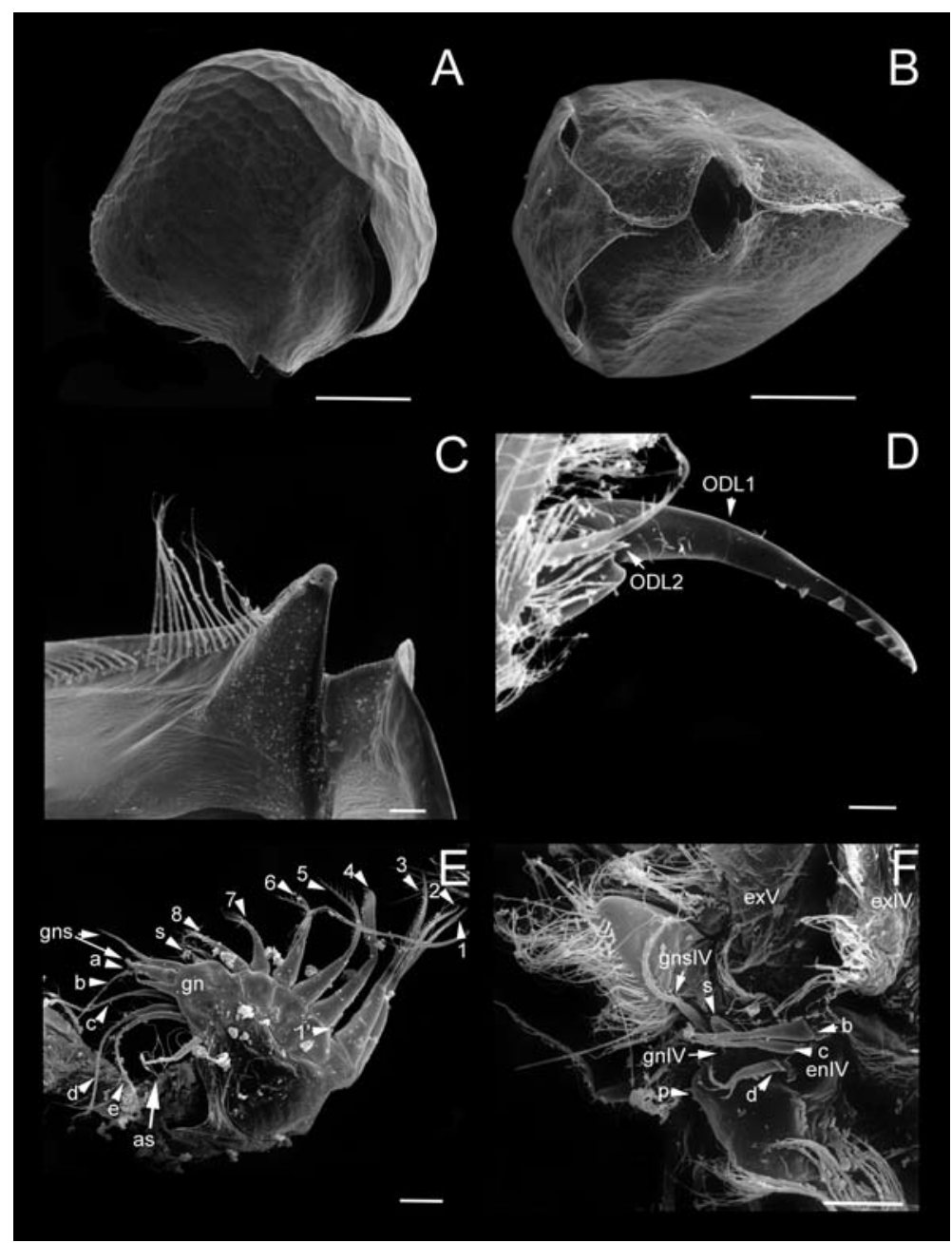

Fig. 3. Anchistropus emarginatus Sars, morphology adult parthenogenetic female from Belgium, SEM. A. Habitus, lateral view; B. Habitus, ventral view showing the opening of the valves; C. Tip of ventral carapace "tooth" and posteriorly situated setae, seen from inner side; D. Hook-like, modified seta of the outer distal lobe (ODL); E. Second limb, anterior view; arrow indicates Fryer's "anterior spine"; note also the minute sensillum near the base of fourth scraper (fourth from right); F. Endites of fourth and fifth limbs. Scale bars indicate $100 \mu \mathrm{m}$ (A-B) and $10 \mu \mathrm{m}(\mathrm{C}-\mathrm{F})$.

postabdominal margin. Groups of lateral denticles in postanal part forming two rows, seven to eight groups in dorsal row, four to five in ventral row. In anal part, smaller groups, ten to 15 , with denticles oriented forwards. Marginal spines long and fine, 11-13, implanted submarginally on postanal margin. Second and third with additional smaller spine, last three consisting of groups of two to four spines. Pre- and postanal corner not expressed. Base of postabdomen twice as broad as terminal part. Basal claw long and fine, as long as ventral margin of postabdomen. Two long basal spines, largest only slightly longer than diameter of terminal claw base. Denticles on dorsal margin of claw strong and evenly spaced.

Maxilla I (Fig. 4A). Consisting of three finely setulated setae, of which middle ( 2 in Fig. A4) longest, implanted on a joint base. Setae not thickened, but slender.

Trunk Limb 1 (P1). (Figs 3D \& 4B-C) Corm large, with spinules or setules on inner side (Fig. 4B). Epipodite globular, ejector hooks short and with sparse 


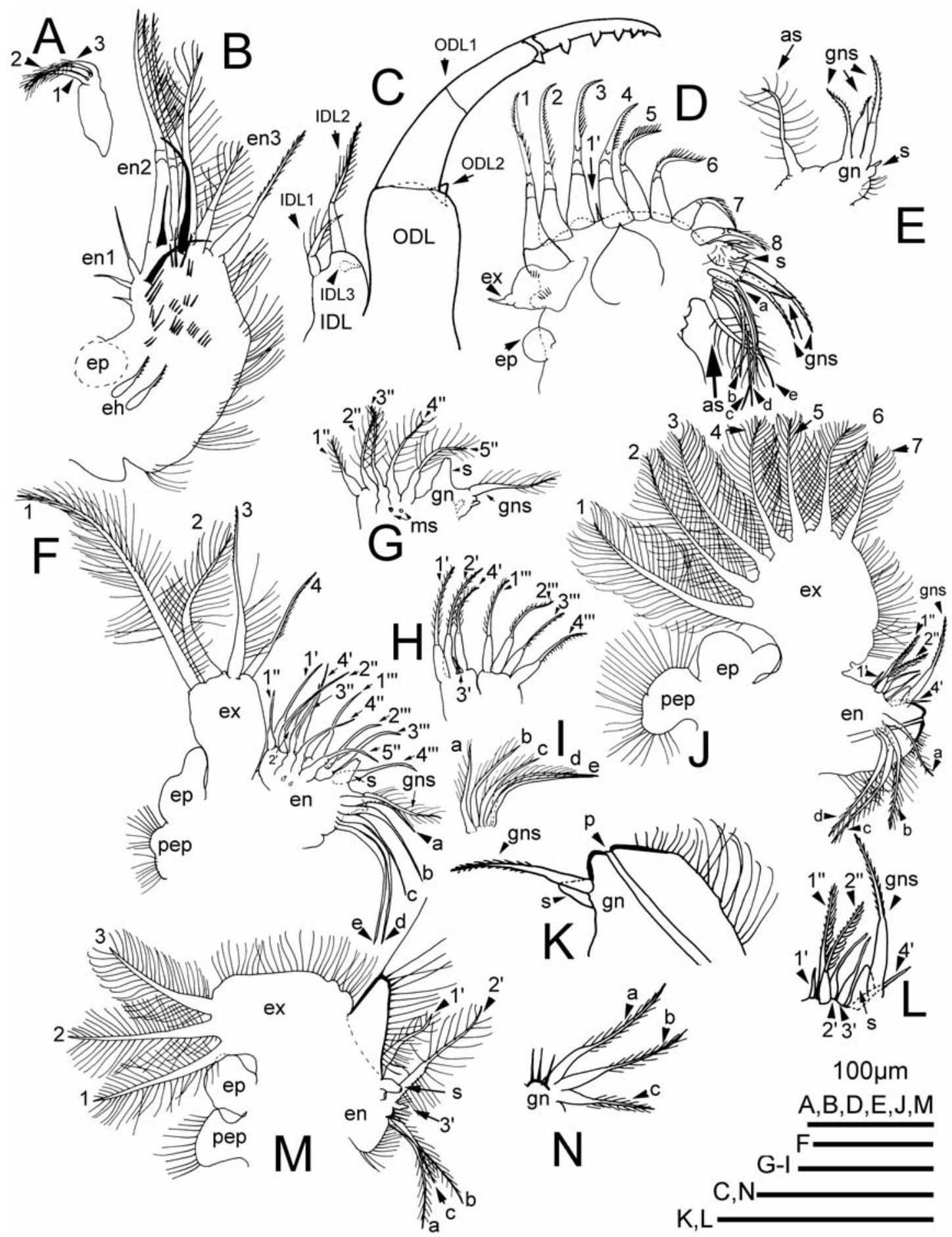

Fig. 4. Anchistropus emarginatus, adult parthenogenetic female from Belgium, trunk limb morphology. A. Maxilla I; B. First limb, anterior view; ODL and IDL removed; C. First limb, IDL (left) and ODL (right). D. Second limb, posterior view; arrow indicates Fryer's "anterior spine"; E. Second limb, gnathobase and Fryer's "anterior spine" (arrow); F. Third limb; G. Third limb, inner endite setae (five setae left) and gnathobase; H. Third limb, outer endite setae; I. gnathobasic comb; J. Fourth limb; K. Fourth limb, inflated gnathobase and two gnathobasic elements; L. Fourth limb, outer endite setae (left) and two gnathobasic elements (right); M. Fifth limb; N. Fifth limb, gnathobase. 
denticulation. Endite 1 with three short setae present and additional soft inner seta. Endite 2 with three equally long, feathered setae and short anterior seta. Endite 3 with three setae, of different length, two plumose, one denticulate, and long anterior soft seta. Outer distal lobe (ODL) elongated, ending in strong chitinized claw armed with six to eight stout denticles on inner, concave side of its proximal half (Figs 3D \& 4C); a small structure (reduced seta) at base of claw (Figs 3D \& 4C). Inner distal lobe or IDL (Fig. 4C) with two relatively short plumose setae and third, smaller naked seta, implanted subterminally.

Trunk Limb 2 (P2). (Figs 3E \& 4D-E). Epipodite small and globular (Fig. 4D). Exopodite with one short seta. Eight slender scrapers lining ventral margin of limb body, gently decreasing in size towards gnathobase (Figs 3E \& 4D). All these setae strongly chitinized in their proximal half and with long fine spines (scrapers seven and eight more setulated); armament of scrapers heterogeneous, with latter three scrapers more sparsely armed, fourth scraper having a clear pecten (Fig. 3E). A minute naked appendix (1') between third and fourth scraper (Fig. 4D). Gnathobase with one naked receptor and three modified setae, of which middle one smallest, bearing minute denticles on terminal half. Both others longer, more slender, spinulated. Filter comb with five slender setae (a-e). Somewhat separated from filter comb and implanted on gnathobasic margin, an anterior, strongly plumose seta near base of limb (Figs 3E \& 4E), oriented towards food groove ("anterior spine" of Fryer 1968), of same size as last gnathobasic comb seta. Parts of second trunk limb sclerotized (gnathobase and base of some scrapers).

Trunk Limb 3 (P3). (Figs 4F-I). Limb with many reductions (Table 1). Pre-epipodite small and setulated. Epipodite oval to bean-shaped (Fig. 4F). Exopodite squarish, with four setae, all implanted terminally (Fig. 4F). Externalmost of these setae one third longer than following three, of approximately the same size. Internalmost of these setae not plumose but denticulated on one side. Endites with inner row of five setae (1"-5", accompanied by two minute sensilla), of which first two smaller than following three and implanted higher, all with plumose setulation (Fig. 4G). Outer row consisting of seven slender setae (Fig. $4 \mathrm{H}$ ), of similar size and arrangement, arranged in two groups (1', 2', 4' and 1'"-4'"); between third and fourth setae, one minute appendix ( 3 ' in Fig. 4H). Gnathobase with one large receptor, a long terminal sweeping seta and two minute elements (Fig. 4G). Gnathobasic comb with five slender setae bearing fine setules (a-e in Fig. 4I).
Trunk Limb 4 (P4). (Figs 3F \& 4J-L). Pre-epipodite rather large and globular, setulated. Epipodite oval to bean-shaped (Fig. 4J). Exopodite with seven plumose setae, gradually decreasing in size interiad. Fused endite rather plump, with six setae: four naked (1'-4') on outer side and two setulated (1"-2"), situated more inward (Fig. 4L), followed by large receptor (s in Figs 3F \& 4L). Gnathobase with chitinized margin, swollen and with two appendages: the large receptor and a long slender seta (Figs $3 \mathrm{~F} \& 4 \mathrm{~K}$ ). Gnathobasic filter plate consisting of four similar plumose setae on the inner side (a-d in Fig. 4J), implanted basally on gnathobase. A canal opens in a pore at apex of gnathobase, connecting to a gland inside. Further towards food groove, a row of setules on gnathobase (Fig. 4K).

Trunk Limb 5 (P5). (Figs 3F \& 4M-N). Pre-epipodite setulated and globular. Epipodite of similar size and shape. Exopodite broadly oval with three plumose setae on ventral margin. Inner lobe a conical, marginally chitinized outgrowth between exopodite and gnathobase, with long setules (Figs 3F \& 4M). Between this lobe and filter comb, two setae with sparse plumose setulation and a receptor near base of second seta (Fig. $4 \mathrm{M})$. Adjacent to this broad receptor, an elevated pore and at base of second plumose seta, a reduced seta (or sensillum?; Fig. 4N). Further towards gnathobase, a chitinized projection with crown of three to five strong spines (Fig. 4N). Gnathobasic comb with three long, setulated setae. Base of limb beyond gnathobasic comb with sparse setulation.

Ephippial female and male. Not studied. See Floessner (2001), Lilljeborg (1901) and Negrea (1983) for drawings of male A. emarginatus.

Distribution. The type locality of A. emarginatus is Lake Bogstadvand, Norway (Sars 1861). This Palearctic species has not been found south of the Pyrenees and is sporadical throughout Europe. Single records are known from Italy and Romania (Margaritora 1985, Negrea 1983). Not recorded from Spain (Alonso 1996). Eastern part of range extending to temperate continental Asia, reaching China (Chiang \& Du 1979).

Ecology. We found A. emarginatus in mesotrophic water in association with Hydra attenuata Pallas, 1766 living on submerged macrophytes (mainly Potamogeton pectinatus Linnaeus, 1753). This association is typical (Fryer 1968, Floessner 2001, Smirnov 1992) and related to its feeding ecology. The species is mostly recorded in low numbers. Individuals may sporadically occur in the pelagic (Floessner 2001), as in one Belgian site (Damvalleimeer), or even in waterbodies with no littoral vegetation (Luyten 1934). Slow swimmer, attaches strongly to objects using its claws (Sars 1861). 
Table 1. Comparison of limb morphology between Anchistropus and Pseudochydorus and rather 'typical' Chydorinae Pleuroxus, Chydorus, Alonella, Dunhevedia and Ephemeroporus. Data based on drawings and descriptions of Smirnov et al. (2006) for P. aduncus-species and Alonso (1996) for C. sphaericus, A. excisa, D. crassa and E. phintonicus. Modifications (most are reductions), are shown in bold. Notation of setae in numbers, reduced setae indicated by "+" followed by number; numbers between brackets indicate structures which are minute. Abbreviations: arm: armament, as: anterior seta, ee: external endite, eh: ejector hooks, en: endite, ex: exopodite, gns: gnathobasic seta(e), max: maxilla; gp: gnathobasic plate (filter comb), ie: internal endite, il: inner lobe, P1-6: thoracic limbs one to six, s: sensillum, ss: soft seta.

\begin{tabular}{|c|c|c|c|c|c|c|c|}
\hline & Anchistropus & Pseudochydorus & Chydorus & Pleuroxus & Alonella & Dunhevedia & Ephemerop. \\
\hline $\max$ I setae & setulated & spinulated & setulated & setulated & setulated & setulated & setulated \\
\hline P1eh & equal & equal & equal & unequal & equal & unequal & equal \\
\hline P1enl setae & $3+s s$ & $2+s s$ & $4+s s$ & $4+$ ss & $3+s s$ & $4+$ ss & $4+s s$ \\
\hline P1en1 setae & short & long & long & long & long & long & long \\
\hline P1en2 setae & $3+s s$ & $3+s s$ & $3+\mathrm{ss}$ & $3+s s$ & $3+s s$ & $3+\mathrm{ss}$ & $3+s s$ \\
\hline Plen3 setae & $3+\mathrm{ss}$ & $3(+s s)$ & $3+\mathrm{ss}$ & $3+\mathrm{ss}$ & $3+s s$ & $3+\mathrm{ss}$ & $3+s s$ \\
\hline P1ODLsetae & hook $(+1)$ & $1+1$ & $1+1$ & $1+1$ & $1+1$ & $1+1$ & 1 \\
\hline ODL spines & absent & strong & small & absent & small & absent & absent \\
\hline P1IDLsetae & $2+1$ & $2+$ hook & $2+$ hook & $2+$ hook & 3 & 3 & 3 \\
\hline Plen6 setae & $\mathbf{0}$ & $\mathbf{0}$ & $\mathbf{0}$ & 1 & $\mathbf{0}$ & 1 & 1 \\
\hline P2ex setae & 1 & 1 & 1 & 1 & 1 & 1 & 1 \\
\hline P2en ant set & 8 & 8 & 8 & 8 & 8 & 8 & 8 \\
\hline P2en post set & 1 & 2 & 1 & (1) & 0? & 0? & 0? \\
\hline P2 gp setae & 5 & 5 & 8 & 8 & 8 & 8 & 8 \\
\hline $\mathrm{P} 2$ as & 1 & 1 & - & - & - & - & - \\
\hline P2 gnath & $3+s$ & 3 & $3+1$ & $3+s$ & $3+s$ & $3+s$ & $3+s$ \\
\hline P2 $3^{\text {d }}$ gns & simple & simple & bifurcate & bifurcate & bifurcate & bifurcate & $?$ \\
\hline P3ex setae & 4 & 7 & 7 & 7 & 7 & 7 & 7 \\
\hline P3ee" setae & 5 & 4 & 6 & 6 & 6 & 6 & 6 \\
\hline P3ee' setae & $3+1$ & $3+1$ & $2+2$ & $2+3$ & $2+2$ & $3(+1 ?)$ & $2+3$ \\
\hline P3ie"' setae & 4 & $4+1$ & 4 & $4+1$ & 5 & 5 & 5 \\
\hline P3gp setae & 5 & 5 & 8 & 8 & 8 & 8 & 8 \\
\hline P3gp arm & homogen. & heterogen. & homogen. & homogen. & homogen. & homogen. & homogen. \\
\hline P3gn midset & long & long & short & short & short & long & short \\
\hline P4ex setae & 7 & 7 & 7 & 7 & 7 & 7 & 7 \\
\hline P4ee" setae & 2 & 4 & 4 & 4 & 4 & 4 & 4 \\
\hline P4ee' setae & $4+s$ & $2(+3)+s$ & $4+s$ & $4+s$ & $4+1+s$ & $4+s$ & $4+s$ \\
\hline P4gns & 1 & $1+2$ & $1+2$ & $1+2$ & $1+2$ & $1+2$ & $1+2 ?$ \\
\hline P4gn & inflated & not infl. & not infl. & not infl. & not infl. & not infl. & not infl. \\
\hline P4gp setae & 4 & 4 & 6 & 6 & 6 & 6 & 6 \\
\hline P5ex setae & $3 ?$ & 4 & 4 & 4 & 4 & 4 & 4 \\
\hline P5il & conical & oval-round & oval-round & oval-round & oval-round & oval-round & oval-round \\
\hline P5il setules & long & short & short & short & short & short & short \\
\hline P5en setae & $2+1+s ?$ & $2+s$ & 2 & $2+s$ & 2 & $2+s$ & $2+s$ \\
\hline P5gp setae & 3 & 3 & 3 & 4 & 4 & 4 & 4 \\
\hline P6 & absent & absent & absent & absent & absent & absent & absent \\
\hline
\end{tabular}




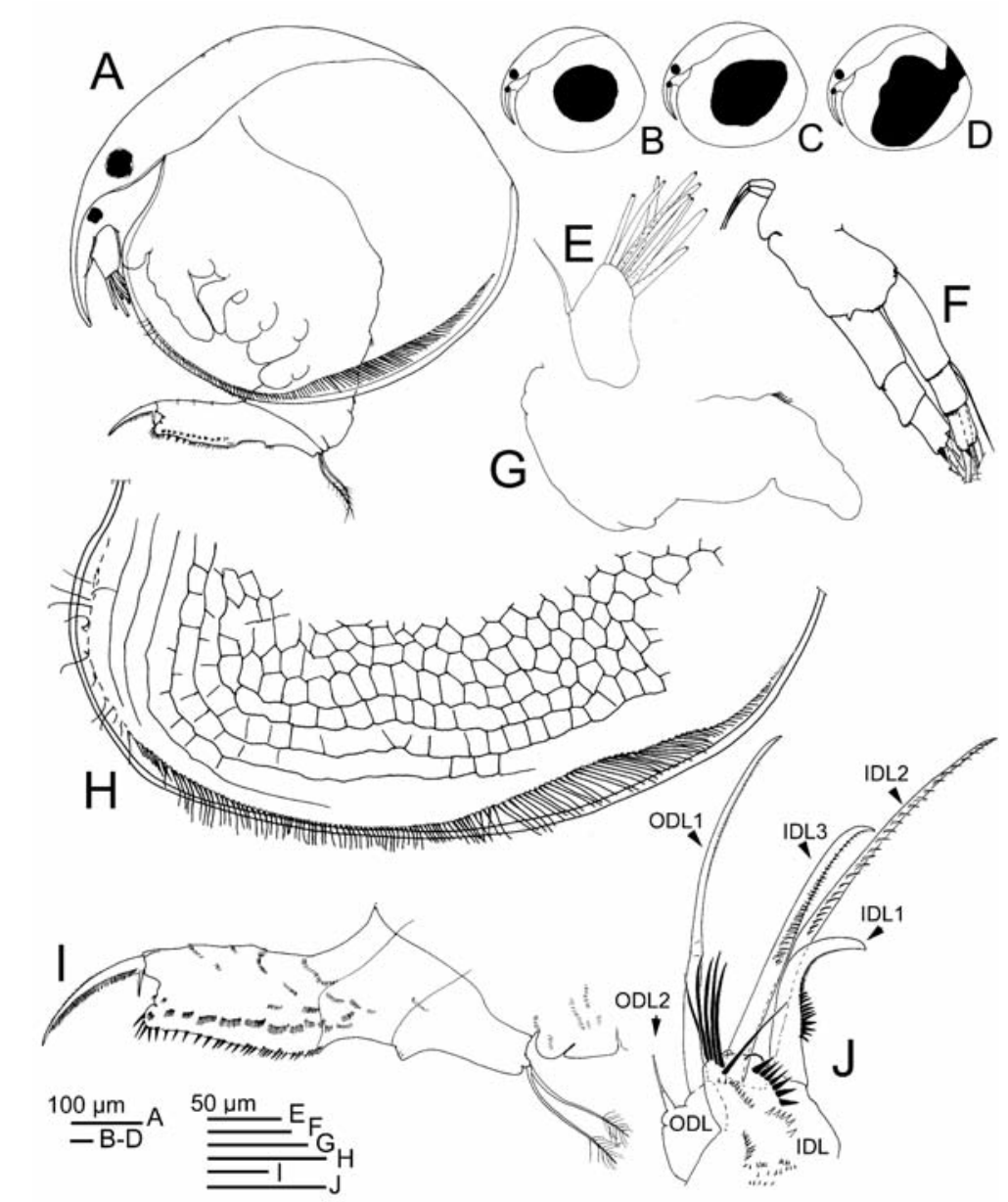

Fig. 5. Pseudochydorus globulosus adult parthenogenetic females from Belgium. A. Habitus, lateral view; pigment field on carapace not shown; B-D. Habitus, lateral view showing common variations in pigment fields; E. Antennule; F. Second antenna; G. Labrum; H. Carapace margin, lateral view; I. Postabdomen, lateral view; J. ODL and IDL (first limb).

\section{Genus Pseudochydorus Fryer, 1968}

Pseudochydorus globosus (Baird, 1843)

Syn. Chydorus globosus Baird, 1843; Chydorus globosus in Frey (1959); synonymy in Floessner (2001) and Smirnov (1992).

Specimens examined: 8 parthenogenetic females from the Ghent Boatracing canal, Belgium. (leg. K. Van Damme, 06/07/2006); 45 parthenogenetic females from Canal Gent-Terneuzen at Desteldonk, Belgium (leg. K. Van Damme \& D. Van Damme, 15/09/2006), 26 parthenogenetic females from Damvallei, Destelbergen, Belgium (leg. K. Van Damme, 20/09/2006).

Redescription of the parthenogenetic female

Habitus (Figs 5A-D \& 6A). Chydorine habitus, glo- bular, carapace brownish, with deeply brown pigment field, often bicoloured. Dimensions: body height/ length $0.82-0.86$. Relatively large-sized, $0.4-0.65 \mathrm{~mm}$. Head pores situated close to one another, of chydorine type (two major pores with small pores in the middle); PP distance (between posterior pore and post. margin head shield) eight times IP distance (between main pores); distance between anterior pore and rostral tip twelve IP distances. Dark lateral pigment fields vary from near-absent to central-round (Fig. 5B), oval (Fig. 5C) or with dorsal connection (Fig. 5D). In young specimens, spot faint to absent. Carapace with cuticle (Fryer 1968) thickened in pigmented region (Fig. 6A). Ornamentation consisting of hexagons (Fig. $5 \mathrm{H} \& 6 \mathrm{H}$ ), sometimes with dimples at transverse connections of hexagons (Fig. 6A) (caelatus form). Ventral margin of 


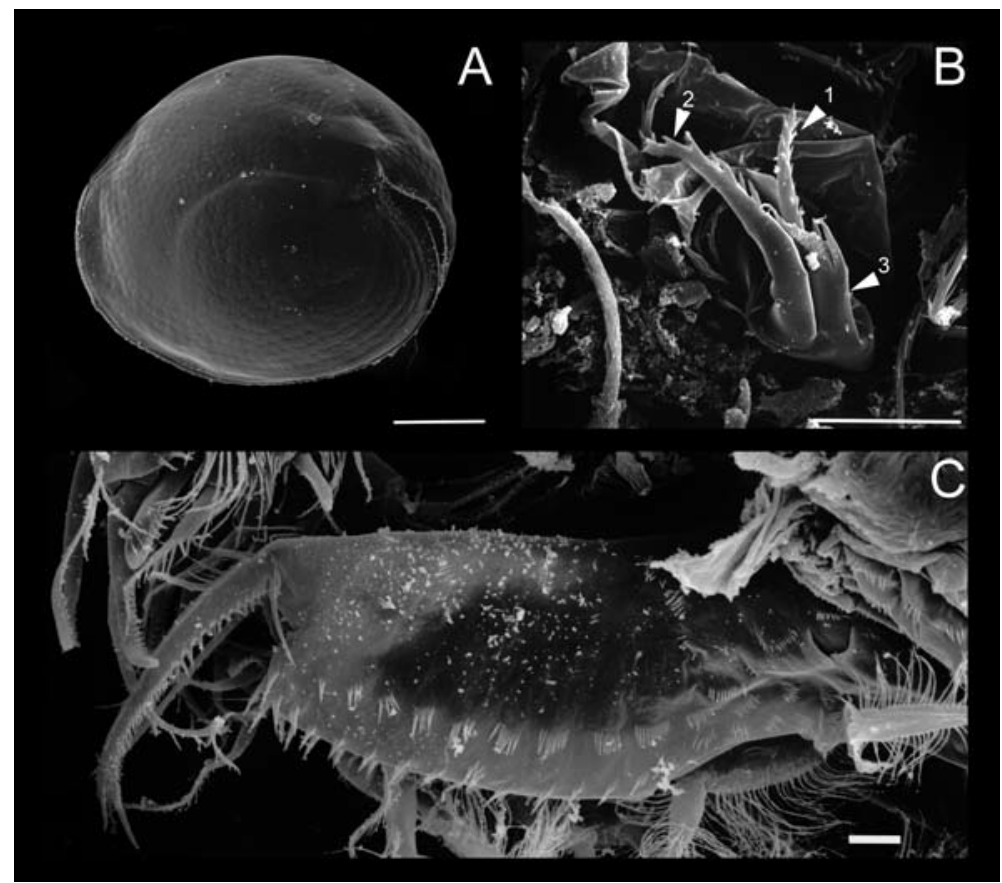

Fig. 6. Pseudochydorus adult parthenogenetic female from Belgium, SEM. A. Habitus, lateral view; B. Maxilla I; C. Postabdomen, lateral view. Scale bars indicate $100 \mu \mathrm{m}$ (A) and $10 \mu \mathrm{m}$ (B-C).

carapace thickened but without flange; marginal setae longest in posterior half, where the row of setae bends inwards. In life, marginal setae not protruding beyond ventral carapace margin.

Antennule (Fig. 5E) with stout body and nine long aesthetascs (longer than antennular body) of different size; sensory seta implanted about halfway on antennular body. Second antenna (Fig. 5F) relatively short, with normal coxal setae; antennal formula 003/013 for setae, (1)01/001 for spines. Minute denticles on margins of segments; apical spines on exo- and endopodite short. Labrum (Fig. 5G) small and fleshy (keel reduced).

Postabdomen (Figs 5I \& 6C) long and saw-like, with straight parallel dorsal and ventral margins, slightly tapering distally. Length (between implantation natatorial setae and posterodorsal angle) more than three times width (at postanal part). Postanal angle little less than $90^{\circ}$. Anal margin short, about half the size of postanal margin. Marginal denticles (Figs 5I \& 6C) 14-18 single teeth, sometimes (one to five) groups of two to three such denticles towards anal margin. Lateral fascicles variable in number, with 10-14 groups of setules parallel to dorsal margin, with number of spinules in each group increasing proximally (lowest number dis- tally, see Fig. 6C). Basal claw long (longer than anal margin) and slender, with two basal spines; proximal basal spine small, about as long as claw width (at base), which is less than three times the length of longest basal spine. Dorsal pecten with strong denticles in two groups: proximal half of claw with strong, more widely spaced denticles, distal row with finer spinules, situated closer together (Fig. 6C).

Maxilla I (Figs 6B \& 7A). Consisting of three modified setae, of which the middle one ( 2 in Figs $6 \mathrm{~B} \& 7 \mathrm{~A}$ ) is the longest, twice as large as other two. Setae thickened, bearing strong spines; in the shortest seta (3), two subterminal spines larger surpassing setal apex, while in others $(1,2)$ two transverse rows of spines on inner margin of each seta.

Trunk limb 1 (P1). (Figs 5J \& 7B). Endites 1-3 with three feathered setae each and anterior soft seta. ODL (outer distal lobe) with two setae, of which one strongly reduced, small and naked, the second long and serrate. IDL (inner distal lobe) with three setae of which two shortest strongly chitinized and smallest curved and hook-like. Five to seven large spines on IDL near base of hooklike seta, and six to eight long (and strong) setules near inner margin of IDL (Fig. 5J). 


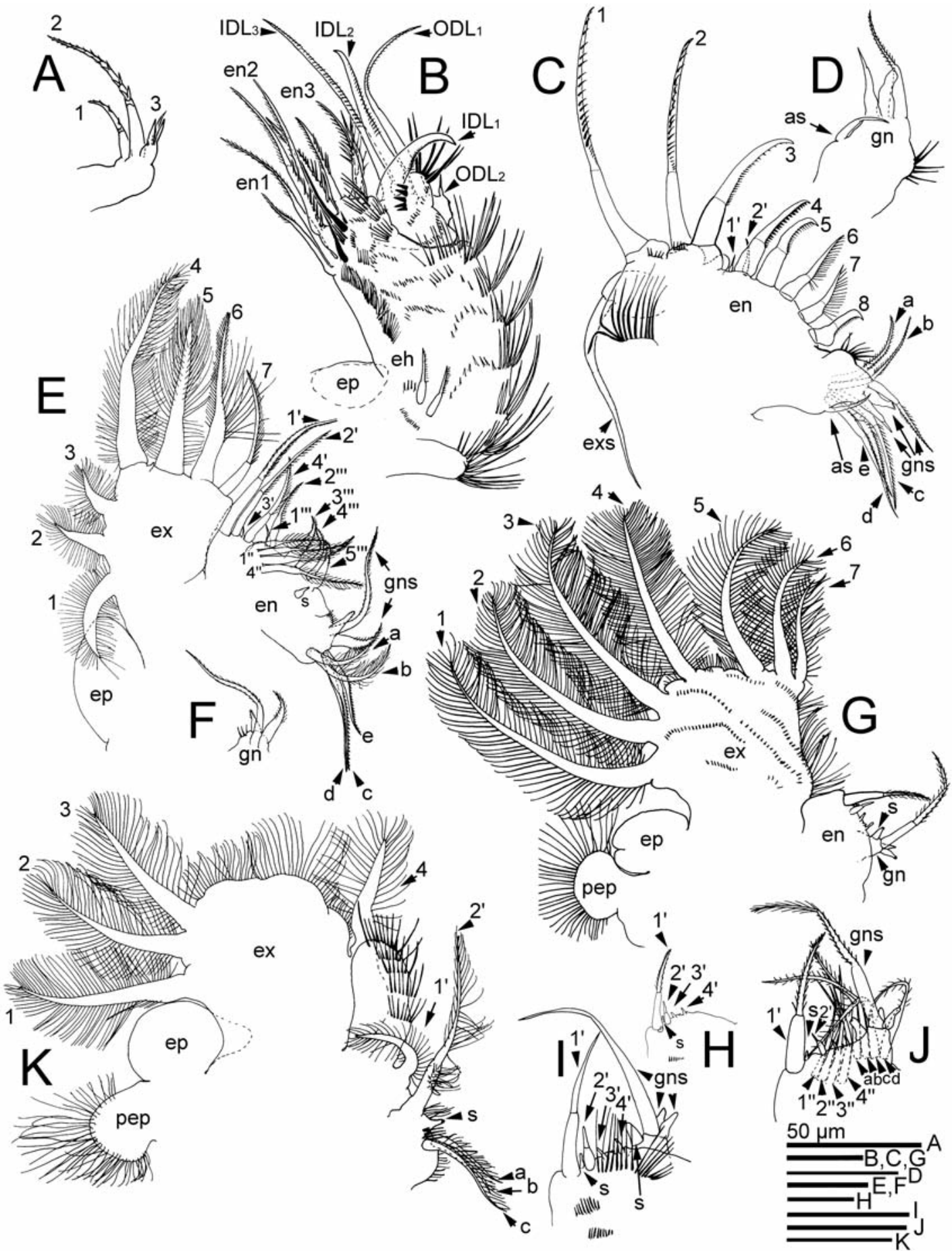

Fig. 7. Pseudochydorus adult parthenogenetic female from Belgium, trunk limb morphology. A. Maxilla I with detail of smallest modified seta viewed from different direction (arrow); B. First limb, anterior view; C. Second limb, anterior view; arrow indicates Fryer's "anterior spine"; D. Second limb, gnathobasic elements and "anterior spine" (arrow); E. Third limb; F. Third limb, gnathobasic elements; G. Fourth limb; inner setae on endite not shown (see Fig. 7J); H. Fourth limb, outer endite setae; I. Fourth limb, setules on outer endite and gnathobase; J. Fourth limb, endites and gnathobase; K. Fifth limb. 
Trunk limb 2 (P2). (Figs 7C-D). Epipodite not seen. A chitinized joint at frontal base of limb, lined by row of long setules. Exopodite with one large seta, as long as first ventral seta. Fused endite with eight heterogeneous setae (scrapers 1-8) along its ventral margin (Fig. 7C). First and second long and seta-like, lined by some stiff setules. Third shortened and with chitinized base; fourth adorned with pecten of thicker denticles. A small posterior seta (1') between third and fourth scraper, and additional small seta (2') behind scraper four. Sixth and seventh scrapers setulated instead of denticulated. All scrapers chitinized in their proximal half. Gnathobase with chitinized hillock bearing a crown of spinules. Three gnathobasic elements, middle one a blunt naked seta with terminal pore, inner one also naked. Gnathobasic plate with five slender setae (a-e) of similar size, adorned in terminal half with two rows of short spinules. Separated from filter comb and situated deeper on gnathobase, a single naked, short seta, about half the size of innermost filter seta.

Trunk limb 3 (P3). (Fig. 7E-F) Epipodite oval. Exopodite squarish, with seven robust marginal setae, of which three (1-3) rather short and thick, implanted along ventral margin. Setulation of exopodite setae fine plumose, except for sixth seta that bears extra long setules on its dorsal side, near the middle, and last exopodite seta, which is unilaterally armed with short setules. A minute process at base of fourth exopodite seta. Endite with three long setae and small seta (3') between second and third seta. Next endite with row of five external setae (1"'-5"'), first one reduced. On inner side of same endite, a row of four plumose setae $\left(1^{\prime}-4\right.$ ') and a small receptor situated halfway between this row and gnathobase on inner side of endite. Gnathobase (Fig. 7F) with one large receptor and two setae, of which middle conspicuously large. Gnathobasic plate consisting of five setae (a-e) altogether, first two with fine setulation, following three with short denticles in their proximal half.

Trunk limb 4 (P4). (Figs 7G-J). Epipodite oval, preepipodite round. Exopodite broad, its body lined with long rows of small spines, its free margin lined with seven strong, plumose setae, gently decreasing in size inwardly. Distance between fourth and fifth seta twice as large as between all other setae. Endite with one external seta, followed by four minute, naked elements, of which only second one half the size of first seta (1'-4' and s between 1' and 2' in Fig. 7I-H). Larger receptor of this row of elements (s in Fig. 7G) shifted towards gnathobase. Four inner setae (1"-4" in Fig. 7J) long and with plumose setulation. Gnathobase with one large seta, surrounded by three small elements, one of which is a sensillum ("s" in Fig. 7G), the others naked elements without pore. On inner face of endite, adjacent to gnathobase, a row of four similar, finely setulated setae (a-b), makes up the gnathobasic plate (Fig. 7J).

Trunk limb 5 (P5). (Fig. 7K). Epipodite and pre-epipodite of similar size, rounded. Epipodite with short broad projection. Exopodite square, with three setae on external surface, and one on inner margin. Inner lobe with about five transverse rows of long fine spinules. A plumose seta at its foot, followed by a second, long plumose seta with receptor at its base. Further towards food groove, gnathobase $\mathrm{V}$ bears a row of spines, followed by three well-developed, finely setulated setae of the gnathobasic plate.

Ephippial female and male. Not included in this study. First description and figures of male in Sars (1861).

Distribution. Originally described from the United Kingdom from "ditch near Richmond; pond near Isleworth" in Baird (1843). Cosmopolitan (Smirnov 1992) and widespread, but populations outside temperate Eurasia should be re-examined and compared with the present description, as $P$. globosus may well be restricted to this region (See Discussion).

Ecology. Occurs in oligo- to slightly eutrophic waters, in association with submerged macrophytes (e.g. Potamogeton), and in the littoral zone of freshwaters (Floessner 2001). Rarely found in large numbers and with patchy distribution (Baird 1835). Not a strong swimmer, according to Baird (1843) "its motion is very much like that of a Cypris". Feeds mainly on dead crustaceans (Fryer 1968). The species is considered typical for large waterbodies $\left(>15,000 \mathrm{~m}^{2}\right)$, sporadical in small $\left(<5,000 \mathrm{~m}^{2}\right)$ ponds (Fryer 1985). In Belgium, we found $P$. globosus as the dominant cladoceran in two canals connected to the rivers Leie and Schelde. In contrast to the ecological preferences noted by Floessner (2001), the water was turbid, eutrophic and contained little to no vegetation.

\section{Discussion}

\section{Limb morphology of Anchistropus and Pseudo- chydorus}

The limb morphology of Anchistropus and Pseudochydorus confirms their appartainance to the Chydorinae, since trunk limb 1 has 2 appendages on the ODL (against 2 in most Aloninae) and trunk limb 4 has 7 exopodite setae. In Anchistropus, the modification of the ODL of trunk limb 1 to a giant claw, and reduction in size of the IDL is easily understood in a feeding context. The reasons for the shortening of the setae of 
endite 1 are less obvious, but likely also relate to food manipulation. Since this involves no particle gathering, the seta-like shape of the scrapers of the second limb suggests a function of gently brushing instead (Fryer 1968). The loss of three setae from the exopodite of the third limb (see Table 1 for comparison with other Chydorinae), however, is difficult to explain in a feeding context, since these setae sit on the outside of the exopodite, away from the food groove. In contrast, the compact shape of the fused endites of the fourth limb, with a strong reduction in setation and with storage capacity for an internal gland suggests that a liquid is secreted. That the fourth, internal and isolated seta of the fifth limb has apparently been lost, finally, is functionally hard to interpret. It is unique in Chydoridae. However, it may be that this seta is shifted further towards the gnathobase, while the first endite seta became reduced.

In Pseudochydorus, in contrast, a "standard" chydorine $\mathrm{P} 1$ is found (Table 1 ), that has the almost universal arrangement of endites 1-3 (three marginal and one anterior seta each), an IDL with three setae, one of which is claw-like, and an ODL with two setae. P2 has scrapers that are individually specialized, partly setulated, partly denticulated, with the fourth seta the "strongest" one. Specific characters include the presence of a short additional seta behind the latter, and the extra seta isolated from the gnathobasic filter comb (Fryer's "anterior spine").

The latter seta was also found in Anchistropus, and other chydorine genera should be examined for its presence. P3 has a full armament of the exopodite (seven plumose setae), and a fairly typical fused endite but shows generally less reductions than Anchistropus; the gnathobasic filter plates (filter combs) are less extensive than in other chydorines (Table 1). P4 stands out by its denticulated exopodite (known from benthic alonine genera Leydigia, Leydigiopsis and some Alona) and reduced endite armament (no flaming-torch setae, low number of filter setae). P5, finally, is again typical for the subfamily, except for the combs of setae on the inner lobe.

\section{Position within the subfamily Chydorinae}

By their habitus, mandibular arrangement, head pores, postabdomen and trunk limbs, both Pseudochydorus and Anchistropus are typical Chydorinae. To some extent, their globular body may suggest affinities with Chydorus, but both Anchistropus and Pseudochydorus have undergone strong specializations and are clearly genera in their own right. Comparing their trunk limb morphology with other Chydorinae (Table 1) reveals that Anchistropus and Pseudochydorus show a relatively large number of modifications to accompany their ecological preferences. Most of these are reductions of setae e.g., in endites III or gnathobasic filter combs. However, a few primitive features occur, such as the presence of two reduced posterior setae on the second limb in Pseudochydorus, remainders of a complete row in primitive radopods (e.g. Eurycercus, Acantholeberis). As well, both have unique adaptations, such as the first maxilla in Pseudochydorus (unique even in Anomopoda), or the strong hook and modified inner lobe $\mathrm{V}$ of Anchistropus.

In support of his hypothesis that both share a common ancestor, Fryer listed 16 similarities (Fryer 1968: 345) between Anchistropus and Pseudochydorus. However, many of these may be the result of convergence rather than parallelisms. For example, the hook-like seta on the first limb, used for collecting soft tissue, originates in both from a different structure: in Anchistropus, it is part of the ODL, while in Pseudochydorus, it belongs to the IDL. The same may be true for the thickening and darkening of the carapace, which does not imply common ancestry but may be related to the diet of these animals. On the other hand, the number of setae in the gnathobasic plates II to V are identical (Table 1, "gp setae"), different from all other Chydorinae, and anterior setae on gnathobase II are present in both. The latter structure seems unique to both genera, though this should be re-checked in other taxa (as it may be homologous to the last seta of the filter comb in other chydorines, which is in a similar position).

While both taxa show deep modifications, trunk limb morphology shows that they are clearly derived from a chydorine ancestor. It is uncertain whether either originates directly from a filter feeder, though $\mathrm{An}$ chistropus seems to have evolved from a Chydoruslike animal that took the leap from grazing filamentous algae to preying on hydras. To conclude, Pseudochydo$r u s$, while having a sufficient number of characters to justify its demarcation in a genus in its own right, is a rather typical chydorine (relatively more primitive than Anchistropus). Anchistropus, in contrast, has a much larger number of morphological modifications. A much closer common ancestry between Pseudochydorus and Anchistropus than with other chydorine genera is not confirmed by our analysis. The morphology of Anchistropus and Pseudochydorus may well be the result of convergence to accompany similar feeding modes (soft tissue). It is possible that both have evolved from Chydorus or Pleuroxus-like ancestors, but likely not from the same single ancestor, Pseudochydorus being relatively more primitive. Molecular data of the complete SSU rDNA gene (Van Damme et al. 2007), show 
Anchistropus in a clade with Chydorus, separate from Pleuroxus, which does not contradict the above. However, no molecular comparison of Anchistropus with Pseudochydorus has been done thus far.

\section{Ecological note}

Both Anchistropus and Pseudochydorus have a peculiar feeding ecology, respectively as parasites and scavengers (Fryer 1968). Anchistropus should, however, be called a carnivore, not a parasite. It is lethal to its prey and may quickly destroy a population of $\mathrm{Hydra}$ (Hyman 1926). Our observations (Fig. 1) confirm Anchistropus to tear off and ingest pieces of ectoderm from unprotected regions of the hydra body but not from the tentacles with cnidocytes, as observed in A. minor by Hyman (1926). Pseudochydorus, on the other hand scavenges on carrion (Fryer 1968). Both genera have a limb morphology that diverges from that of other Chydorinae to allow them to feed on soft tissue instead of small particles. The specificity of this diet was not studied in detail here but Hyman (1926) observed that Anchistropus populations decline in the absence of Hydra and Fryer (1968) suggested that Pseudochydorus is an obligate scavenger that cannot be cultured on a diet of detritus and algae.

\section{Rarity of Anchistropus}

A. emarginatus is described as rare in all regions where it was recorded (Sars 1861, Negrea 1983, Floessner 2001, Margaritora 1983, Luyten 1934, ...). The same applies to A. minor in North America (Hyman 1926). This rarity may -at least partly- be attributed to the tight physical attachment of the animal to its prey, which makes it difficult to dislodge and collect. Also, Anchistropus will only develop in numbers while Hydra is common. These chydorids, by their parthenogenetic reproduction, may quickly react to prey availability, and thus develop sharp peaks in short periods of time. On the other hand, a short generation time and life expectancy may serve to keep these peak periods short. In Belgium, 2006 appears to have been a good hydra year, and Anchistropus was found in several localities, unlike in preceding years, and in 2007.

\section{Taxonomical note: how many species of Pseudochydorus are there?}

We think that at least two more species may be hidden under this taxon. Stating the concept of non-cosmopolitanism (Frey 1987) in chydorid distributions, Frey (1993) applied the name P. cf. globosus to popu- lations from Australia and South Africa. It is not unlikely that at least one of these will be described as a different species in the future. We briefly examined two specimens from Eastern Africa, and found that differences in limb morphology may be present, but more material for comparison is necessary. A figure of South American specimens in Hollwedel et al. (2003) also reveals differences in the IDL and first maxilla with European $P$. globosus; the authors note that South American populations should be re-evaluated but descriptions of European populations are limiting. With the present re-description at hand, populations of P. globosus from outside the Palearctic can now be compared in detail.

\section{Acknowledgements}

We thank the MSc-students in Biology at Ghent University and MSc B. Rumes, who brought A. emarginatus to our attention during the Limnology Course, June 2006. The first author would like to thank Dr D. Van Damme for help during sampling, valuable ideas and comments and to two anonymous reviewers for fine-tuning of this manuscript.

\section{References}

Baird W. 1835. - The natural history of the British Entomostraca. Ann. Mag. Nat. Hist., 11, 81-95.

Borg F. 1935. - Zur Kenntnis der Cladoceren-Gattung Anchistropus. Zool. Bidr. Upps., 15, 289-330.

Chiang S. \& Du N. 1979. - Fauna Sinica. Crustacea. Freshwater Cladocera. Science Press, Academia Sinica, Peking, China.

Dumont H.J. \& Negrea S.V. 2002. - Introduction to the class Branchiopoda. Guides to the identification of the microcrustaceans of the continental waters of the world 19. Backhuys Publishers, Leiden.

Floessner D. 2001. - Die Haplopoda und Cladocera Mitteleuropas. Backhuys Publishers, The Netherlands.

Frey D.G. 1959. - The taxonomic and phylogenetic significance of the head pores of the Chydoridae (Cladocera). Int. Rev. Hydrobiol., 44, 27-50.

Frey D.G. 1987. - The taxonomy and biogeography of the Cladocera. Hydrobiologia, 145, 5-17.

Frey D.G. 1993. - The penetration of cladocerans into saline waters Hydrobiologia, 267, 233-248.

Fryer G. 1968. - Evolution and adaptive radiation in the Chydoridae (Crustacea: Cladocera): a study in comparative functional morphology and ecology. Philos. T. Roy. Soc. B, 254, 221-285.

Fryer G. 1985. - Crustacean diversity in relation to the size of water bodies: some facts and problems. Freshwater Biol., 15, 347-361.

Hollwedel W., Kotov A.A. \& Brandorff G.-O. 2003. - Cladocera (Crustacea: Branchiopoda) from the Pantanal (Brazil). Arthropoda Selecta, 12(2), 67-93.

Hyman L.H. 1926. - Note on the destruction of Hydra by a chydorid cladoceran, Anchistropus minor Birge. T. Am. Microsc. Soc., 45, 298-301.

Kotov A.A. 2000. - Redescription and assignment of the chydorid Indialona ganapati Petkovski, 1966 (Branchiopoda: Anomopoda: Aloninae) to Indialonini, new tribus. Hydrobiologia , 439, 161-178. 
Luyten M. 1934. - Over de oecologie der Cladocera van België. Biologisch Jaarboek Dodonaea, 25, 33-179.

Louette G., De Bie T., Vandekerkhove J., Declerck S. \& De Meester L. 2007. - Analysis of the inland cladocerans of Flanders (Belgium) - Inferring changes over the past 70 years. Belg. J. Zool., $137,117-123$.

Lilljeborg W. 1901. - Cladocera Sueciae. Facsimile Reissue of the Original Edition with a Prologue. Rodhe W. \& D.G. Frey (Eds.). Almqvist \& Wiksell Intl. Stockholm, Sweden.

Margaritora F. G. \& Specchi M. 1985. - Cladocera. Fauna d'Italia, 32. Edizioni Calderini Bologna, 399 pp.

Negrea S. 1983. - Fauna Republicii Socialiste România. Crustacea Volumul IV, Fascicula 12, Cladocera. Editura Academiei Republicii Socialiste România, Bukarest, 399 pp.

Sars G. O. 1861 (published in 1993). - On the freshwater crustaceans occurring in the vicinity of Christiania. Edited by Christiansen M.E. et al., University of Bergen, 199 pp, 113 plates.
Smirnov N.N. 1971. - Chydoridae fauny mira. Fauna USSR. Rakoobraznie, 1(2), Leningrad, 531 pp. (English translation: Chydoridae of the world. Israel Program for Scientific Translations, Jerusalem, 1974).

Smirnov N.N. 1996. - Cladocera: the Chydorinae and Sayciinae (Chydoridae) of the World. In: Guides to the Identification of the Microinvertebrates of the Continental Waters of the World (Volume 11). Coordinating editor: H.J. Dumont. SPB Academic Publishing, Amsterdam, The Netherlands.

Smirnov N.N., Kotov A.A. \& Coronel J. 2006. - Partial revision of the aduncus-like species of Pleuroxus Baird, 1843 (Chydoridae, Cladocera) from the southern hemisphere with comments on subgeneric differentiation within the genus. J. Nat. Hist., 40, 1617-1639.

Van Damme K., Shiel R. J. \& Dumont H. J. 2007. - Notothrix halsei gen. n., sp. n., representative of a new family of freshwater cladocerans (Branchiopoda, Anomopoda) from SW Australia, with a discussion of ancestral traits and a preliminary molecular phylogeny of the order.Zool.Scr., 36 (5), 465-487. Note by the authors: important nomenclatural Corrigendum of this paper in Zool. Scr., 36 (6), 623. 